\title{
Understanding the Learning Challenges of English-Medium Instruction Learners and Ways to Facilitate Their Learning: A Case Study of Taiwan Psychology Students' Perspectives
}

Entender los desafíos de aprendizaje de los estudiantes de asignaturas en inglés y formas de facilitar su aprendizaje: un estudio de caso de las perspectivas de estudiantes de psicología de Taiwán

Compreender os desafios da aprendizagem dos alunos de disciplinas em inglês e maneiras de facilitar seu aprendizado: um estudo de caso das perspectivas de estudantes de psicologia de Taiwan

Tzu-Ling HUA

Ming Chuan University, Taiwan tzuling@mail.mcu.edu.tw https://orcid.org/oooo-oooI-9345-586I

Received: 22/09/2019

Accepted by peers: $14 / 02 / 2020$
Sent to peer review: 09/01/2020

Approved: 20/02/2020

DOI: 10.5294/laclil.2019.12.2.6

To reference this article (APA) / Para citar este artículo (APA) / Para citar este artigo (APA) Hua, T-L. (2019). Understanding the Learning Challenges of English-Medium Instruction Learners and Ways to Facilitate Their Learning: A Case Study of Taiwan Psychology Students' Perspectives. Latin American Journal of Content \& Language Integrated Learning, 12(2), 321-340. https://doi.org/10.5294/laclil.2019.12.2.6 
ABSTRACT. English-medium instruction (EMI) has become a global education phenomenon in recent decades, especially in higher education. However, its implementation is still facing criticism. On the one hand, learners are welcoming the envisaged benefits of preparing them with professional content knowledge and English language proficiency to compete in the new global economy; on the other hand, they are reluctant to take the courses because of the challenges and difficulties EMI creates. Meanwhile, EMI lecturers are concerned about students' inability to survive, or better still thrive through EMI learning. EMI lecturers are expert in their professional domain but are not trained or prepared to teach EMI courses yet. This qualitative study examines the perception of first-year undergraduate students taking the EMI foundation psychology course in Taiwan, focusing on their perspectives of factors facilitating or hindering their EMI learning, and their suggestions for improving the situation. The results not only point out what kinds of teaching practice contribute to challenges for EMI learners in their learning process, but also the underlying reasons and the pedagogy practice that students suggest can be used to improve the situation. Insights provided by this study can be used to assist EMI lecturers in examining their own pedagogical practice and expand their knowledgeability about pedagogy. They can also be used as a way forward for assisting in the development of EMI teacher training and professional development, and the implementation of EMI.

Keywords (Source: Unesco Thesaurus): English-medium instruction; EMl; higher education; teacher training; psychology; students' perspectives.

RESUMEN. El inglés como medio de instrucción (EMI) se ha convertido en un fenómeno educativo global en las últimas décadas, especialmente en la educación superior. Sin embargo, su implementación aún se enfrenta a críticas. Por un lado, los estudiantes reciben de buena manera los beneficios previstos de prepararlos con conocimiento en contenidos profesionales y un buen dominio del inglés para competir en la nueva economía global; por otro lado, son reacios a tomar los cursos debido a los desafíos y dificultades que general el EMI. Por su parte, los profesores de EMI se preocupan por la incapacidad de los estudiantes de sobrevivir, o mejor, progresar a través del aprendizaje en inglés. Los profesores de EMI son expertos en su área profesional pero aún no están capacitados ni preparados para enseñar cursos en inglés. Este estudio cualitativo examina la percepción de estudiantes de primer año de pregrado de un curso básico de psicología en inglés en Taiwán, enfocándose en sus perspectivas de los factores que facilitan u obstaculizan su aprendizaje en inglés, y sus sugerencias para mejorar la situación. Los resultados indican no solamente los tipos de práctica docente que contribuyen a los desafíos que enfrentan los estudiantes de los cursos en inglés en su proceso de aprendizaje, sino también las razones subyacentes y la práctica pedagógica que, de acuerdo con los estudiantes, pueden usarse para mejorar la situación. Los conocimientos proporcionados por este estudio se pueden utilizar para ayudar a los profesores de EMI a examinar su propia práctica pedagógica y a ampliar su conocimiento sobre la pedagogía. Estos también se pueden usar en adelante para ayudar en el desarrollo de la capacitación y el desarrollo profesional del profesor de EMI, así como en la implementación del EMI.

Palabras clave (Fuente: tesauro de la Unesco): Inglés como medio de instrucción; EMI; educación superior; capacitación docente; psicología; perspectivas de los estudiantes.

RESUMO. O inglês como meio de ensino (EMI) tornou-se um fenômeno educacional global nas últimas décadas, especialmente no ensino superior. No entanto, sua implementação ainda enfrenta críticas. Por um lado, os estudantes recebem de maneira positiva os benefícios esperados de sua preparação com conhecimentos de conteúdo profissional e um bom domínio do inglês para competir na nova economia global; por outro lado, eles estão relutantes em se inscrever nos cursos devido aos desafios e dificuldades que o IME gera. Os professores de EMI, por sua vez, estão preocupados com a incapacidade dos alunos de sobreviver, ou melhor, progredir através do aprendizado em inglês. Os professores de EMI são especialistas em sua área profissional, mas ainda não estão treinados ou preparados para ministrar cursos em inglês. Este estudo qualitativo examina a percepção dos alunos de primeiro ano de um curso básico de psicologia em língua inglesa em Taiwan, concentrando-se em suas perspectivas sobre os fatores que facilitam ou dificultam o aprendizado em inglês e em suas sugestões para melhorar a situação. Os resultados indicam não apenas os tipos de práticas de ensino que contribuem para os desafios que os alunos dos cursos em inglês enfrentam em seu processo de aprendizagem, mas também os motivos subjacentes e a prática pedagógica que, de acordo com os alunos, podem ser usados para melhorar a situação. Os conhecimentos fornecidos por este estudo podem ser usados para ajudar os professores de IME a examinar sua própria prática pedagógica e expandir seus conhecimentos de pedagogia. Eles também podem ser usados no futuro para ajudar no desenvolvimento do treinamento e do desenvolvimento profissional dos professores de EMI, bem como na implementação do EMI.

Palavras-chave (Fonte: tesauro da Unesco): Inglês como meio de instrução (EMI); Educação superior; formação de professores; psicologia; perspectivas dos alunos. 
A growing global education phenomenon, especially in higher education, is the adoption of English-medium instruction (EMI) (Llieva \& Peak, 2017). EMI refers to "the use of the English language to teach academic subjects in countries or jurisdictions where the first language (L1) of the majority of the population is not English" (Dearden, 2014, p. 4). The main reasons behind this global education phenomenon include: first, bringing prestige and raising national and international ranking for the university; secondly, creating market-forces for universities to become sufficiently internationalized to attract foreign students; and thirdly, increasing instrumental advantages, global mobility, competitiveness, and employability for home students (Cho, 2012; Lei \& Hu, 2014a; Macaro, Curle, Pun, An, \& Dearden, 2018).

EMI is envisaged as beneficial for universities, teachers, and students in responding to the need for internationalization of higher education and to compete in the new global economy (Belhiah \& Elhami, 2015; Morell, Aleson, Bell, Escabias, Palazon, \& Martinez, 2014). However, switching the medium of instruction from L1 to English is not without problems. Macaro et al. (2018)'s systematic review of 83 EMI studies, which investigated university teachers' and/or students' beliefs, between 2000 and 2015 in different geographical areas, found that, in virtually all studies consulted, the most often expressed concerns were student's English language proficiency, the lecturer's ability to teach in English, or both, which created a barrier for students' comprehension.

Lecturers see student proficiency as inadequate and are deeply concerned about "their students' inability to survive, or better still thrive, when taught through English" (Macaro et al., 2018, p. 52). Macaro et al. (2018) further point out several studies that reported that students' perceptions of their English proficiency are in line with those of their lectures, and that students have difficulty understanding their lectures.

To deal with learners' lecturing comprehension related to language, most EMI lecturers resort to translation, code-switching (CS) or code-mixing (CM) (Yeh, 2012). However, it has been discovered that, in many cases, there is a large and/or unnecessary amount of translation taking place in the classroom (Airey, Lauridsen, Räsänen, Salö, \& 
Schwach, 2017; Chang, 2010). This raises legitimate concerns with the conflicts between the policy and its actual implementation (Ariffin \& Husin, 2011). Moreover, it has been reported that, while CS/CM may be favored by the less proficient students, students with better English proficiency felt that such practice is off-putting. It may jeopardize students' ability to answer examination questions in English, and not prepare them for the linguistic competence for their future career (Ariffin \& Husin, 2011). CS/CM appears to be a short-term tactic rather than a long-term solution to EMI students' comprehension problems. EMI teachers' pedagogical strategy may be used ineffectively, and there are still challenges to deliver EMI lectures in a way that is comprehensible and supportive of students' learning.

It has been argued that EMI policies are, in many cases, uncritically adopted (Walkinshaw, Fenton-Smith, \& Humphreys, 2017). Its implementation is made without adequate planning or preparation for teachers and students (Kirkpatrick, 2017). Without adequate planning or preparation, the adoption of EMI can have unintended consequences. For example, the actual needs of the EMI stakeholders are not appropriately addressed (Lei \& Hu, 2014a). There are gaps between what the EMI program promised, and what it could actually achieve (Byun, Chu, Kim, Park, Kim, \& Jung, 2011; Lei \& Hu, 2014b). This can bring about adverse effects on educational outcomes (Simasiku, Kasanda, \& Smit, 2015), which in turn can lead to resistance to EMI policy (Al-Kahtany, Faruk, \& Al Zumor, 2016; Cho, 2012). This is the case in Taiwan. While EMI has been promoted through a series of policy statements and funding schemes, it not only engendered a heated debate on its implementation from professors (Chang, 2017), but also resulted in reluctance of local English as a foreign language (EFL) students to take the course (Po-hsuan \& Hetherington, 2018). As suggested by Byun et al. (2011), there is a need to examine how to effectively implement EMI in higher education and how to reduce its side effects.

EMI lecturers are expert in their professional field, but this does not entail their competence and skills to teach their subject content matter in a language that is their L2, nor does it entail their understanding and awareness of language pedagogy practice that can support students' learning through EMI. Without having sufficient knowledge or awareness of EMI students' learning situations and difficulties, 
EMI lecturers' pedagogy could turn out to not facilitate students' learning, and indeed frustrate their learning efforts instead (Kyeyune, 2003). It has been found that even lecturers with a high language proficiency are not necessarily perceived by students as having supportive lecturing behaviour (Klaassen, 2001). Therefore, Klaassen (2001) argues that it is important for lecturers to be aware of the ways in which they can support the students' learning process, and this is especially important in an EMI instructional setting.

Instead of focusing on students' English proficiency for their EMI learning difficulties, this study aims to examine students' EMI learning, with a particular focus on identifying factors students perceive as hindering their learning, and also pedagogical strategies and practice students suggest that could facilitate and support their learning. This examination can help us understand the possible underlying reasons that contribute to students' reluctance to EMI learning, as the situation mentioned earlier in Taiwan. It can also contribute to our understanding of beneficial pedagogical practice and EMI students' actual learning needs that, as preceding discussion shows, many EMI lecturers are currently unaware of. Such understanding can help EMI lecturers and policy makers improve and support the EMI learning situation, and better facilitate the implementation of EMI.

\section{Review of relevant literature}

\section{The medium of instruction language}

EMI lecturers tend to assume that mother tongue lectures do not differ significantly from EMI lectures. They express that they hardly experience/display differences between performing teaching duties, teaching behaviors and didactic skill in English and in their L1 (Klaassen, 2001; Vinke, Snippe, \& Jochems, 1998). Yet, it has been reported that didactic skills and student needs are perceived by students to be different from L1 and English medium instruction. For example, Dutch students that received Dutch-medium or English-medium instruction from Klaassen's (2001) study perceived effective lecturing behavior differently. 
The English group considered clarity as the most important lecturing behavior, whereas the Dutch group perceived every lecturing behavior having a similar role of importance. Students from Yip, Coyle, and Tsang's (2007) study perceive that their EMI lecturers tended to adopt a more didactic approach and use fewer interactive activities than Chinese as the medium of instruction (CMI) teachers.

EMI adds another layer of difficulty for students' learning, as students need to comprehend not just specialist subject matter, but do it through a L2/foreign language, which is a language they may not be familiar with. Accordingly, EMI increases the complexity of the transfer of the subject-matter (Klaassen, 2001) and students' study burden (Lei \& Hu, 2014a). EMI students may need extra/more time to achieve similar disciplinary results as L1 programs (Airey et al., 2017).

In addition, second-language lecture comprehension research has pointed out that academic listening for the majority of university study is very different, or even in contrast to conversational listening that students are often trained with in schools. Examples of such difference are the type of background knowledge required, the degree of concentration required on long stretches of talk, and the ability to integrate the incoming message with information derived from handouts or textbooks (Flowerdew, 1994). Therefore, EMI lecture comprehension process and learning is different from L1 as medium of instruction and requires a different lecturing pedagogy and approach to meet students' learning needs.

\section{EMI lecturing pedagogy}

Several pieces of research have shown that effective lecturing pedagogy, especially in terms of lecturing behavior and approach, can contribute to EMI students' comprehensibility, motivation, engagement, and attention (Chuang, 2015; Flowerdew, 1994; Klaassen, 2001; Suviniitty, 2010).

When examining the differences between the most and the least comprehended lectures, Suviniitty (2010) found that the lectures perceived by students as most comprehensible revealed a notable presence of interactional features in them. The use of questions tends to improve comprehension of lectures. Similarly, Flowerdew, Miller, and Li's (2000) study reveals several pedagogy practices which students 
perceived as making comprehension easier, such as systematic presentation of information, summarizing lecture points, lecturer's responses to students' questions, lecturer initiating interaction with students during the lecture, and repetition of main points. Klaassen's (2001) study also confirms that effective lecturing behavior, such as the application of structure, interaction, and presentation, is perceived by students as supportive to their understanding of EMI lectures and beneficial to their learning, concentration, and attention span.

A few studies have been carried out by EMI lecturers, which demonstrate good teaching practices by addressing learners' EMI learning issues and concerns. For example, Chow (2018) demonstrates how the adoption of a case-based approach, the utilization of multiple teaching methods, non-verbal communication skills, and clear and guided instruction can help to address the issue of having mixed nationality students in an EMI course, and students' concerns of language and cultural barriers. Students in her study reported that such effective teaching pedagogy can help to engage students from different cultural backgrounds in discussion, and bring about additional positive learning, such as increased interaction between teachers and students, improved knowledge retention, and ease anxiety. In the same vein, in order to address EMI learners' poor lecture comprehension and passive engagement in class, Chuang (2015) carried out several experiments to trail and examine if her adapted teaching pedagogy, which takes into account her teaching experiences in EMI courses, and her past students' learning situations and difficulty, can help to facilitate EMI students' learning experiences and lecture comprehension. She claims and then demonstrates that when lecturing pedagogy methods attend to students' learning situations, it can help to improve/facilitate EMI students' learning.

The research above has shown that EMI students' lecturing comprehension and learning difficulties can be facilitated and improved through effective lecturing pedagogy. The learners, as Klaassen (2001) puts, are the decisive factor in the definition of effectiveness. It is believed that pedagogical understanding begins from listening to learners' voice regarding their learning. Giving consideration to their voice can generate highly effective pedagogy, and lead to improved teaching and learning (Husbands \& Pearce, 2012). Accordingly, it is essential to allow students to voice their EMI learning experience and difficulties and to consider ways they perceived as helpful to facilitate their learning. 
This study employed a qualitative method research design to investigate EMI learners' experience and perspectives on their EMI learning. As Gillham (2000) argues, "open questions can lead to a greater level of discovery" (p. 5), an open-ended questionnaire was first given to students as a research strategy to primarily explore and gain an understanding of the issues by allowing the students to be more accurately reflect and express their thoughts in their own manner (Kelley, Clark, Brown, \& Sitzia, 2003). Students were asked the following two questions:

1. What are the factors facilitating or hindering your EMI learning?

2. What are your suggestions to facilitate your EMI learning?

After collecting individual perspective through an open-ended questionnaire, a focus group was utilized as the next step for its features of widening the range of response and several perspectives on those themes reoccurred in the open-ended questionnaire (Dilshad \& Latif, 2013), and filling knowledge gaps about their underlying causes of those reoccurred themes (Ryan, Gandha, Culbertson, \& Carlson, 2014). Thirty students were purposely selected because they showed differing levels of participation in class, ranging from high participation to low participation. Students were contacted in advance and were made aware of the objective of the interview. Each interview lasted appropriately 30-40 minutes and was recorded with each student's consent. Two recorders were used simultaneously to ensure the quality of the recording. The audio recordings were transcribed verbatim.

Both sets of open questionnaire and interview data were analyzed qualitatively, using a content analysis method with a systematic procedure outlined in Taylor-Powel and Renner (2003). The analysis focuses on the language used by respondents, as well as how they respond to each question in order to identify emerging themes to show the holistic nature of their experience and perspectives. A consistent coding method was applied to enhance the reliability of the study. An independent researcher cross-checked the coding to increase reliability and accuracy. 


\section{Research context and the EMI course}

The Ministry of Education (MOE) of Taiwan has actively encouraged the use of English as the medium of instruction (EMI) in non-language subjects at university level to internationalize Taiwanese higher education (Llieva \& Peak, 2017), and also to prepare local students with international competitiveness. With the government backing and financial incentives, more and more Taiwanese universities have started to offer or have increased the number of EMI courses (Wu, 2006).

The EMI course in this study is a foundation psychology course offered to every first-year undergraduate student at a private university in Taiwan. Each lesson is three hours each week, consisting of three consecutive 50-minute periods. Fifty-nine students participated in this study. The majority of them are local Taiwanese students, with three students from Malaysia and four students from Hong Kong. The lecturer is Taiwanese, and her first language is Mandarin. She received her doctoral degree in America and has worked in psychological related fields in America for nine years before taking up her teaching position in Taiwan. Both the lecturer and the learners were informed about the study and its aims. Those who are willing to participate signed an informed consent form (59 out of 65 students participated).

\section{Results}

Students' open questionnaire responses regarding factors that facilitate/hinder their EMI learning and their suggestions to improve the situations can be grouped into two categories: Category 1. Learning with a L2 itself, and Category 2. Learning new subject content knowledge with a L2. Each category is associated with different themes related to students' EMI learning situations and learning challenges. Each theme is further illustrated with focus group interview data and suggestions provided by students to improve the situation. A summarized table is provided at the end of the session (Table 1). 


\section{Category 1: Learning with a L2 itself}

\section{Learning situation and challenges A: Extra energy \& Concentration}

Students comments highlighted that they must expend extra energy to comprehend the lecture, and they find it tiring and difficult to main-

If the lecture is held in our first language, even when we are doing our own things, we can still get the content. If someone is talking next to me in Mandarin, I am just nearby, I would hear it, understand it, and remember the conversation. However, it is totally different when the language changes to English. If I am looking at information in my mobile phone, I am looking at Mandarin. I cannot get two languages at the same time. Thus, if I do not focus on the lecture, then the lecture becomes a background sound, like birding humming in the background. I wouldn't care what the content is.

Another student further commented that "What made the situation worse is that the lecturer would continue the lesson without any breaks."

The other important factor, as reported by students, that affects their concentration span in an EMI course lies in the lecturer's teaching approach and learning atmosphere. As one student remarks that:

It takes good learning atmosphere, and the lecturer's teaching approach and behaviour to lead us to be focused on learning. I think the lecturer's teaching approach is very rigid, and inflexible, with the same pattern all the time. She just literally reads from the textbook and covers the material in the textbook. Nothing special for her teaching approach. This results in the class atmosphere being completely dead [literal translation "Dead Air"].

Another student commented that the way that the lecturer just follows the textbooks and reads from the textbooks is like "chanting", and this "leads to students' lowered concentration, and further results in discouragement/decreasing level of engagement and participation. This makes us disengaged from the learning". Students think that "the lecture should be held in a more interesting and approachable way", so that it can motivate students to learn. For example, a student stated that:

The topic for this week is about 'Hypnosis and Drugs', which is a boring topic. However, when the lecturer connects the topic to her own 
[experience in America] .... I become interested in her story and can refocus on to the lecture.

Students' response regarding teaching approach is also reflected in other contexts. For example, math teachers in Malaysia are being reported as using English mechanically, and employing a passive "click and show" approach to teaching, which fails to create a meaningful learning environment (Sopia, Marsh, Ong, \& Lai, 2009). Similarly, Airey (2011) also reported that Swedish lectures become less flexible when they change the instruction medium to English and are unable to tell jokes or stories through EMI.

Students' responses show that the EMI course requires extra effort on their part to concentrate on the lecture. Having a regular break is especially important for students to refresh their mind and regain their energy in order to be able to concentrate and comprehend the EMI course. In addition, students suggested that the lecturer's capability for improvisation during the lecture is also critical, not only for maintaining their concentration in the rather demanding EMI course, but also for their learning motivation and engagement.

\section{Learning situation and challenges B: New learning approach \& Affective factor}

Students state that they feel nervous and anxious at the beginning of the course, especially when it comes to speaking or answering questions in English. The emotional anxiety, stress, and nervousness when taking the EMI courses is also evidenced in Yeh's (2012), Huang's (2015), and Yang's (2015) studies. This may be because EMI learners tend to have low confidence in their foreign language (Seikkula-Leino, 2007).

A student in the focus group interview points out another explanation for this issue:

Generally, we do not use English for communication. We just use English when we talk to foreigners. There are rarely any subjects that use English. Only the English language course and EMI psychology course.

EMI learners in this study are mostly Taiwanese and are from an EFL environment. Their exposure to and contact with English is very limited. Therefore, EMI learning approach is very different from the learning environment they are used to being in. This finding echoes 
Thompson and Sylven's (2015) claims that EMI anxiety may be culturally influenced and is likely to change between different contexts.

The implementation of EMI courses should accommodate an Asian EFL context. As suggested by the students in this study, it would probably be good to have an adaptation period to help them get used to the new learning approach. Such a buffer period or a bridging course before EMI courses could help to lessen learners' uncertainty, pressure and anxiety for a greater chance of successful EMI implementation.

\section{Category 2: Learning a new subject content knowledge with a L2}

\section{Learning situation and challenges C: Double challenge \& information processing}

Students mention that, when the subject in the EMI course is new, there is a lack of content knowledge, and the L2 instruction medium just compounds the challenges. Students express in the focus group interview that:

We have never learned Psychology before, we have no basic psychological concept and there are technical terms that we do not even know in Mandarin, it is difficult to comprehend them, let alone in English.

Another interviewee further explained that,

if it were biology or chemistry, which are the subjects that we had learned in school, then we would have some basic idea and knowledge, and even know some technical terms. However, we have never learned psychology before, it is a complete new subject to us.

Students' responses indicate that, when the course subject is completely new to them, and when they do not have any prior knowledge or idea about the subject, their learning challenges can be attributed to the language as medium of instruction, or the content itself, or, maybe that there is no difference between the two. On the other hand, one might equally argue that, when the new subject is taught in students' L2, it creates a further challenge to their learning. Students perceive that EMI would be less challenging if they had previously learned some 
related background knowledge/concepts, and if they were familiar with some of the contents and terminologies.

Students further point out that they had no time to process the content information. They frequently get lost in the lecture because very often new content just keeps coming in when they are still trying to process the content they just heard. Focus group discussion highlighted that students are not familiar with English and require more time to recall the words or process the English language because of the EFL environment in Taiwan. A student remarks that:

We seldom listen to English, maybe just once or twice a week in classes, so we are not familiar with English. As such, when we first hear words or sentences, we may not be able to recall their meaning immediately even though they may be words or sentences that we know.

Another student points out a rather different perspective, stating that:

The way English is structured is different from Mandarin, for example, if and except. They can both be placed at the end of the sentences. However, we would say them first in Mandarin. This takes more time for me to process the information.

This suggests that EMI learners' difficulty in processing English language is associated with the EFL contexts such as in Taiwan and the structural differences between learners' L1 and English.

Students' responses reveal that they encounter a double challenge of having to process new and unfamiliar subject content knowledge as well as a second language. This situation gets worse when the teaching pace does not give them enough time to process the information, especially for EFL EMI learners.

As Coonan (2007) states, the greater the familiarity with the topic, the more there will be associated availability of linguistic and subject-specific schemas (i.e., knowledge of and ability to decode linguistic features and subject-specific information), which can help in understanding and further exploration. It appears that there is a need to take into account not only students' previous related background knowledge, or schema building (Sobhy, Berzosa, \& Crean, 2013), but also students' learning context when considering which subject is going to adopt an EMI approach. 


\section{Learning situation and challenges D: Incomprehensibility \& attentiveness}

Students state that the less proficient learners may think that they do not receive the attention that they need from the lecturer. Focus group interviews explained the situation. Several students said that the lecturer just keeps talking and talking in English but there are not many students who can really absorb the content. What makes the situation worse is that students think that "the lecturer does not care if they sleep in class or not". As they perceive that the lecturer does not care, students just sleep in class or do other non-relevant tasks when they do not comprehend the lecture. A similar situation is also found in Kyeyune's (2003) study, where students felt that there is a lack of teachers' attention to students' learning needs.

Students responses suggest that they need more care, support, and attention from the lecturer, especially for those less proficient learners who are struggling to comprehend the lecture. However, such care, support, and attention are currently absent in practice (Table 1):

Table 1: A summarized table of students' responses to their EMI learning situations, challenges, and suggestions to facilitate their learning

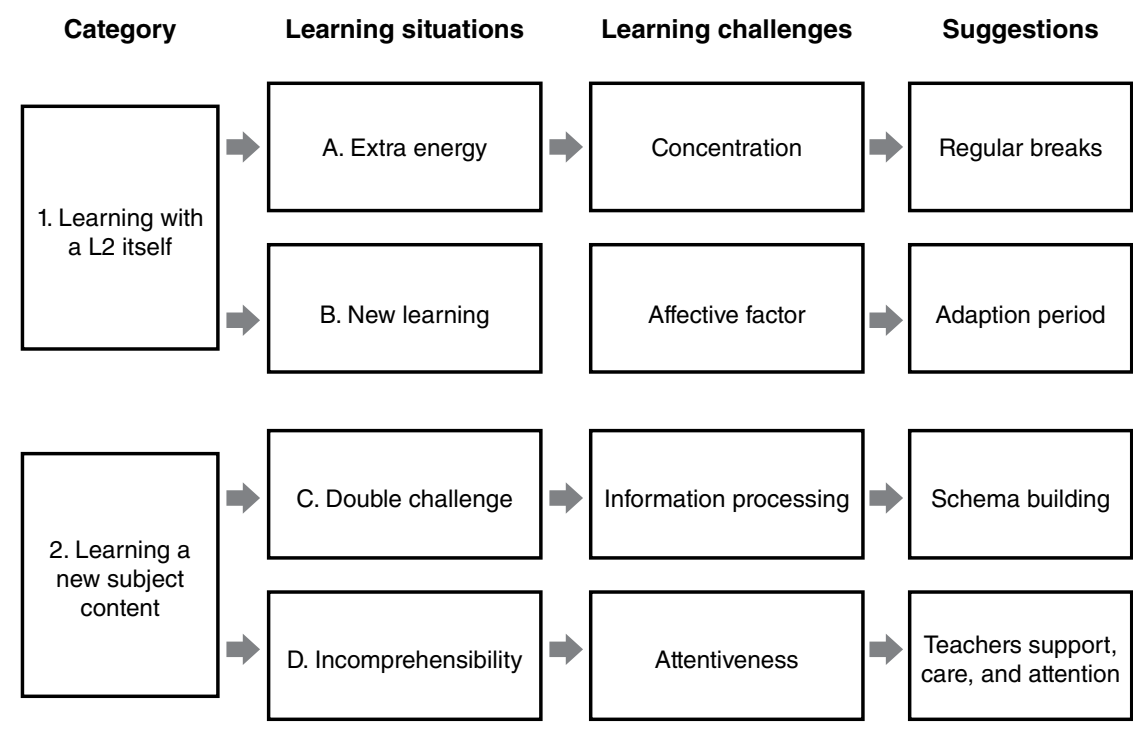

Source: Own elaboration. 


\section{Discussion}

As Eslami (2010) points out, "instructors may not always be the best judges of student's needs and challenges" (p. 7); it is therefore important to understand and take into account learners' perceptions of their learning process when considering changes and/or improvements (Kym \& Kym, 2014). In this respect, this study investigated EMI learners' perceptions and experiences of their learning, and pointed out not only what kinds of teaching practices could contribute to challenges for EMI learners in their learning process, but also investigated the underlying reasons, and pedagogical practices that students perceive would improve the situation.

This study contributes to the current understanding of what factors would hinder students' EMI learning, and what kinds of pedagogy practice could facilitate/support students' learning challenges. The findings of this study can help EMI lecturers be aware of their learners' learning situations and challenges, understand how their teaching pedagogy could help to facilitate EMI learning, and provide adequate support to create a positive learning experience. The findings can also be used as a way forward for assisting in the development of EMI teacher training and professional development.

When learners are active participants in the learning process, their perceptions of their learning can enable EMI teachers and policy makers to respond to their actual needs and problems. Furthermore, it can help to maximize the envisaged benefits and reduce the difficulties created by EMI.

Additional studies can be done to complement the research. First, other EMI courses in the same disciplines and/or other disciplines and contexts can be conducted to examine, compare, and validate if the learners' perspectives also reflect the same results. Longitudinal research can also be carried out to constantly validate the perceptions of the respondents with other parties concerned (Flowered, Miller, \& Li, 2000). Furthermore, this study concentrates on the perceptions of learners, however, other stakeholders' opinions could also be studied. In particular, teacher's perspectives of their pedagogical practices in assisting learners' comprehensibility and learning experiences, and 
consideration if similar or different points can be identified. Innovative teaching approach can also be examined to see what best brings about positive learning experience.

\section{References}

Airey, J. (2011). Talking about teaching in English: Swedish university lecturers' experiences of changing teaching language. Ibérica, 22, 35-54. http://www.aelfe.org/documents/02_22_Airey.pdf

Airey, J., Lauridsen, K. M., Räsänen, A., Salö, L., \& Schwach, V. (2017). The expansion of English-medium instruction in the Nordic countries: Can top-down university language policies encourage bottom-up disciplinary literacy goals? Higher Education, 73, 561-576. https://doi. org/10.1007/s10734-015-9950-2

Al-Kahtany, A. H., Faruk, S. M., \& Al Zumor, A. W. (2016). English as the medium of instruction in Saudi higher education: Necessity or hegemony? Journal of Language Teaching and Research, 7(1), 49-58. https:// doi.org/10.17507/jltr.0701.06

Ariffin, K., \& Husin, M. S. (2011). Code-switching and code-mixing of English and Bahasa Malaysia in content-based classrooms: Frequency and attitudes. The Linguistics Journal, 5(1), 220-247. https://www.linguistics-journal.com/wp-content/uploads/2014/01/June-2011-ka.pdf

Belhiah, H., \& Elhami, M. (2015). English as a medium of instruction in the Gulf: When students and teachers speak. Language Policy, 14, 3-23. https://doi.org/10.1007/s10993-014-9336-9

Byun, K., Chu, H., Kim, M., Park, I., Kim, S., \& Jung, J. (2011). English-medium teaching in Korean higher education: policy debates and reality. Higher Education, 62(4), 431-439. https://doi.org/10.1007/s10734-010-9397-4

Chang, C. (2017). Not all classes need be in English. Taipei Times. http://www. taipeitimes.com/News/editorials/print/2017/09/07/2003677946

Chang, Y. Y. (2010). English-medium instruction for subject courses in tertiary education: Reactions from Taiwanese undergraduate students. Taiwan International ESP Journal, 2(1), 55-84. https://nurulfarhani7971. weebly.com/uploads/2/7/5/4/27546657/emi_3.pdf 
Cho, D. W. (2012). English-medium instruction in the university context of Korea: Tradeoff between teaching outcomes and media-initiated university ranking. The Journal of Asia TEFL, 9(4), 135-163. http://journal. asiatefl.org/main/main.php?inx_journals $=34 \&$ inx_contents $=84 \&-$ main $=1 \&$ sub $=3 \&$ submode $=3 \&$ PageMode $=$ JournalView \&s_title $=$ En glish_medium_Instruction_in_the_University_Context_of_Korea_ Tradeoff_between_Teaching_Outcomes_and_Media_initiated_University_Ranking

Chow, W-C. E. (2018). English-medium instruction in higher education. A case study. Journal of Teaching Practice and Pedagogical Innovation, 1(1), 155-191. https://doi.org/10.1007/s10734-013-9661-5

Chuang, Y. T. (2015). An EMI pedagogy that facilitates students' learning. English Language Teaching, 8(12), 63-73. https://doi.org/10.5539/elt. v8n12p63

Coonan, C. M. (2007) Insider views of the CLIL class through teacher self-observation-introspection. International Journal of Bilingual Education and Bilingualism, 10(5), 625-646. https://doi.org/10.2167/beb463.0

Dearden, J. (2014). English as a medium of instruction — a growing global phenomenon: Phase 1. London, UK: British Council.

Dilshad, R. M., \& Latif, M. I. (2013). Focus group interview as a tool for qualitative research: An analysis. Pakistan Journal of Social Sciences, 33(1), 191-198. https://www.bzu.edu.pk/PJSS/Vol33No12013/PJSS-Vol33-No1-16.pdf

Flowerdew, J. (1994). Research of relevance to second language lecture comprehension: An overview. In J. Flowerdew (Ed.), Academic listening (pp.7-29). New York, NY: Cambridge University Press.

Eslami, Z. R. (2010). Teachers' voice vs. students' voice: A needs analysis approach to English for Academic Purposes (EAP) in Iran. English Language Teaching, 3(1), 3-11. https://doi.org/ 10.5539/elt.v3n1p3

Flowerdew, J., Miller, L., \& Li, D. C. S. (2000). Chinese lecturers' perceptions, problems and strategies in lecturing in English to Chinese-speaking students. RELC Journal, 31(1), 116-138. https://doi.org/ 10.1177/003368820003100106

Gillham, B. (2000). Developing a questionnaire. London, UK: Continuum. 
Huang, D. F. (2015). Exploring and assessing effectiveness of English medium instruction courses: The students' perspectives. 32nd International Conference of the Spanish Association of Applied Linguistics (AESLA): Language Industries and Social Change, 173, 71-78. https://doi. org/10.1016/j.sbspro.2015.02.033

Husbands, C., \& Pearce, J. (2012). What makes great pedagogy? Nine claims from research. Nottingham, UK: NCSL.

Kelley, K., Clark, B., Brown, V., \& Sitzia, J. (2003). Good practice in the conduct and reporting of survey research. International Journal of Quality in Health Care, 15(3), 261-266. https://doi.org/10.1093/intqhc/mzg031

Kirkpatrick, A. (2017). The languages of higher education in East and Southeast Asia: Will EMI lead to Englishisation? In Fenton-Smith, B., Humphreys, P., and Walkinshaw, I. (Eds.), English Medium Instruction in Higher Education in Asia-Pacific: From policy to pedagogy. - (pp. 21-36). Springer International Publishing, Cham, Switzerland.

Klaassen, R, G. (2001). The International University Curriculum: Challenges in English-Medium Engineering Education. Delft: Delft University of Technology, Netherlands

Kyeyune, R. (2003). Challenges of using English as a medium of instruction in multilingual contexts: A view from Ugandan classrooms. Language, Culture and Curriculum, 16(2), 173-184. https://doi. org/10.1080/07908310308666666

Kym, I., \& Kym, M. H. (2014). Students' perceptions of EMI in higher education in Korea. The Journal of Asia TEFL, 11(2), 35-61. http://journal. asiatefl.org $/ \mathrm{main} / \mathrm{main}$.php?inx_journals=40\&inx_contents=49\&main $=1 \&$ sub $=3 \&$ submode $=3 \&$ PageMode $=J$ ournalView \&s_title $=$ Students_Perceptions_of_EMI_in_Higher_Education_in_Korea

Lei, J., \& Hu, G. (2014a). Is English-medium instruction effective in improving Chinese undergraduate students' English competence? IRAL, 52(2), 99-126. https://doi.org/10.1515/iral-2014-0005

Lei, J., \& Hu, G. (2014b). English-medium instruction in Chinese higher education: a case study. Higher Education, 67(5), 551-567. https://doi. org/10.1007/s10734-013-9661-5 
Llieva, J., \& Peak, M. (2017). The shape of global higher education: National policies framework for international engagement. Emerging themes. British Council, UK.

Macaro, E., Curle, S., Pun, J., An, J., \& Dearden, J. (2018). A systematic review of English medium instruction in higher education. Language Teach. 51(1), 36-76. https://doi.org/10.1017/S0261444817000350

Morell, T., Aleson, M., Bell, D., Escabias, P., Palazon, M., \& Martinez, R. (2014). English as the medium of instruction: A response to internationalization. https://pdfs.semanticscholar.org/10a0/7444289ebd069d1511 d576731a424a27131a.pdf

Po-hsuan, W., \& Hetherington, W. (2018). Ministry to push courses in English. Taipei Times. http://www.taipeitimes.com/News/taiwan/archives/2018/05/28/2003693869

Ryan, K., Gandha, T., Culbertson, M. J., \& Carlson, C. (2014). Focus group evidence: Implications for design and analysis. American Journal of Evaluation,35(3),328-345.https://doi.org/10.1177/1098214013508300

Simasiku, L., Kasanda, C., \& Smit, T. (2015). Teaching subjects matter through English as the medium of instruction in the Namibian English second language classrooms. European Scientific Journal, 1, 315324. https://eujournal.org/index.php/esj/article/view/5100/4872

Seikkula-Leino, J. (2007). CLIL learning: Achievement levels and affective factors. Language and Education, 21(4), 328-341. https://doi. org/10.2167/le635.0

Sobhy, N. N., Berzosa, C., \& Crean, F. M. (2013). From ESP to CLIL using the schema theory. BIBLID, 19, 251-267. https://pdfs.semanticscholar.org/aff5/c4488e79a624bfc92d70fb57f79e5aed2c85.pdf?_ ga $=2.140760178 .1777498628 .1585138081-1092456984.1581575866$

Sopia, M. Y., Marsh, D., Ong, E. T., \& Lai, Y. Y. (2009). Learners' perceptions towards the teaching of science through English in Malaysia: A quantitative analysis. International CLIL Research Journal, 1(2), 54-69. http://www.icrj.eu/12/article6.html

Suvinitty, J. (2010). Lecturers' questions and student perception of lecture comprehension. Helsinki English Studies, 6, 44-57. https://blogs.helsinki.fi/hes-eng/files/2010/12/Suviniitty_HES_Vol6.pdf 
Taylor-Powell, E., \& Renner, M. (2003). Analysing qualitative data. Retrieved from https://cdn.shopify.com/s/files/1/0145/8808/4272/files/G3658-12.pdf

Thompson, A. S., \& Sylven, L. K. (2015). Does English make you nervous? Anxiety profiles for CLIL and non-CLIL students in Sweden. Journal of Applied Language Studies, 9(2), 1-23. https://doi.org/10.17011/apples/ urn.201512093950

Vinke, A. A., Snippe, J., \& Jochems, W. (1998). English-medium content courses in non-English higher education: A study of lecturer experiences and teaching behaviours. Teaching in Higher Education, 3(3), 383-394. https://doi.org/10.1080/1356215980030307

Walkinshaw, I., Fenton-Smith, B., \& Humphreys, P. (2017). EMI issues and challenges in Asia-Pacific Higher Education: An introduction. In Fenton-Smith, B., Humphreys, P., and Walkinshaw, I. (Eds.), English Medium Instruction in Higher Education in Asia-Pacific: From policy to pedagogy (pp. 1-21). Switzerland: Cham, Springer International Publishing.

Wu, W. S. (2006). Students' attitudes toward EMI: Using Chung Hua University as an example. Journal of Education and Foreign Language and Literature, 4, 67-84. https://doi.org/10.6372/JEFLL.200612.0067

Yang, W. (2015). Content and language integrated learning next in Asia: Evidence of learners' achievement in CLIL education from a Taiwan tertiary degree programme. International Journal of Bilingual Education and Bilingualism, 18(4), 361-382.https://doi.org/10.1080/13670050.20 14.904840

Yeh, C. C. (2012). Instructors' perspectives on English-Medium Instruction in Taiwanese university. Curriculum and Instruction Quarterly, 16(1), 209-232. http://www.aci-taiwan.org.tw/pdf/16-1/16-1_c05_e.pdf

Yip, D. Y., Coyle, D., \& Tsang, W, K. (2007). Evaluation of the effects of the medium of instruction on science learning of Hong Kong secondary students: Instructional activities in science lessons. Education Journal, 35(2), 77-107. http://hkier.fed.cuhk.edu.hk/journal/wp-content/ uploads/2009/10/ej_v35n2_77-107.pdf 